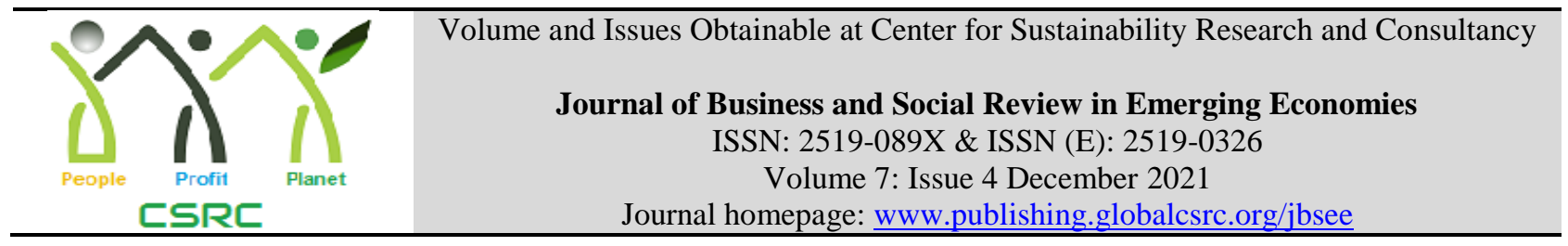

\title{
Impact of Executive Compensation, CEO Compensation and Board Diversity on Organizational Performance with Moderating Effect of Systemic Factors
}

Muhammad Shoukat Malik, Dean, Faculty of Law, Commerce \& Business Administration, Bahauddin Zakariya University Multan, Pakistan

*Noorulain Waheed, Ph.D. Scholar, Institute of Banking \& Finance, Bahauddin Zakariya University /Lecturer University of Education Lahore (Multan Campus), Pakistan

*Corresponding author's email:_noorulain.waheed@gmail.com

\begin{tabular}{l}
\hline ARTICLE DETAILS \\
\hline History \\
Revised format: Nov 2021 \\
Available Online: Dec 2021 \\
\hline
\end{tabular}

Keywords

Executive compensation, CEO compensation, Board gender diversity, organizational

performance,

Systemic factors

JEL Classification

$M 1, M 2$

\begin{abstract}
Purpose: Current research intended to probe the impact of executive compensation, CEO compensation and diversity on the organizational financial performance with the moderating role of systemic factors. Systemic factors are overall country based factors such as political, economic, social and legal factors that may moderate the relationship of executive compensation, CEO compensation, diversity and organizational performance.
\end{abstract}

Design/Methodology/Approach: To conduct study secondary data is collected from annual reports of domestic scheduled public sector banks of 2015-2020. Executive compensation, CEO compensation and board gender diversity are bootstrapped on organizational performance by using MS Excel and Stata17. Linear regression and moderated hierarchical regression analysis is used for data analysis.

Findings: Results shows that Executive compensation, CEO compensation and diversity has signification positive impact on organizational performance. Moreover systemic factors moderates the predictors and outcome relationship

Implications/Originality/Value: This paper explores the relationship of Executive \& CEO compensation, board gender diversity and organizational performance with the moderating role of systemic factors, which has largely been ignored in the previous literature

(C) 2021 The authors, under a Creative Commons AttributionNonCommercial 4.0

\footnotetext{
Recommended citation: Malik, M. S. and Waheed, N. (2021). Impact of Executive Compensation, CEO Compensation \& Board Diversity on Organizational Performance with moderating effect of systemic factors Journal of Business and Social Review in Emerging Economies, 7 (4), 935-947.
} 


\section{Introduction}

In liberal economic settings and country's integration into world market, the current world business community cannot overlook the significance of governance and corporate governance. Governance can be delineated as formulation, continuous monitoring and proper implementation of policies by governing body members of the organization (Connelly et al., 2017). While the term "corporate governance" is now commonplace, its usage is not very consistent. It's a system of rules and practices by which country's relationship with stakeholders are ensured by BOD with the help of accountability, fairness and transparency (Stellner, Klien \& Zwergel, 2015). Numerous scams in the corporate antiquity of the world like Robert Maxwell, Enron and Satyam that attracts the attention of investors towards corporate Governance. Most of the frauds are related to poor corporate governance strategies and due negligence of board of directors. This lead the researcher to study various factors of corporate governance that creates economic turbulence (Haynes et al., 2017). In the current study, researcher have identified executive compensation, CEO compensation and diversity as main contributing factors of corporate governance which may have an impact on organizations financial performance.

In Pakistan, this topic gained importance in the recent times because of the fragile corporate institutional culture and the state observed a very high numbers of corporate failures. Securities and Exchange Commission (SEC) set up a committee that provide amendments in code of corporate governance in 2012 followed by further amendments in 2017 to deal with corporate governance practices in Pakistan and to resume public confidence. Based on the abovementioned, it was clear that this is prerequisite to develop and promote good corporate governance in Pakistan in which executive compensation, CEO compensation and board gender diversity are important contributing factors which may exert influence on financial performance of organization. So, to study these predictors following research question have been developed:

\section{Research Questions of the Study}

This research will answer the following questions

1. How executive compensation affects organizational performance?

2. How CEO compensation affects organizational performance?

3. To what extent diversity affects organizational performance?

4. How systemic factors moderates the relationship of executive compensation, CEO compensation, diversity and organizational performance?

\section{Research Objectives}

Current research would be conducted to study three main corporate governance factors and its influence on organizational performance with moderating role of systemic factors. Main objectives of our research are as follows:

1. To explore the influence of executive compensation, CEO Compensation and diversity on organizational performance

2. To study the extent to which systemic factors moderates the relationship of executive compensation, CEO Compensation, diversity and organizational performance.

\section{Literature Review}

\section{Executive \& CEO Compensation}

Due to the ever increasing prominent corporate catastrophes, the rich, complex and scandalous issue of executive compensation has attracted the attention of shareholders, regulators, the media and the public. This leads to raise questions about suitability of the company structure that regulates executive compensation and the connection between executive compensation plans and company performance. In addition, the company's financial performance is getting more and more attention, especially after the repercussions of the 2007-2009 financial crisis (Coles et al., 2014). The relation between pay and performance is derived from agency theory (Zooning, 
2017). According to agency theory, the design of compensation contracts should make the interests of managers (agents) and shareholders (clients) consistent. Executive compensation is a classic application of principal-agent theory.

\section{Diversity}

In today's business units, the workforce has become increasingly diverse in terms of age, race, gender, tenure, experience, educational background, and socioeconomic status (Darmadi, 2011). Due to this ever increasing diversity, phenomenon of discrimination with minority group (women) has enhances the organizational attempts to encourage equal opportunities. In line with these, corporate governance reforms signify the importance of minority group representation in board of directors (Adams \& Ferreira, 2009).

In addition, the Norwegian and Swedish administrations set gender quotas on the board of directors (Randøy et al., 2006). Like Scandinavian countries, Spain, Iceland and France also approved regulation governing the female representation in board (Ahern \& Dittmar, 2012). Furthermore, according to Companies Act 2017, its mandatory for public interest companies to have women representation in directors as specified by the Securities and Exchange Commission of Pakistan (SECP) and for listed companies the board of such companies shall have at least one woman director (Hayat, 2017). Based on these Board diversity has attracted the interest of researchers from different disciplines. So, in the current research, researcher investigated board diversity and its relationship with organizational performance in Pakistan's context.

\section{Systemic Factors}

A set of interrelated and interdependent parts arranged in a manner that produces a unified whole is called system approach. System dynamically interacts by means of the environments by taking inputs and converting them into outputs that are disseminated into environments (Robbins, 2007). Systemic factor are the ones that come from different levels of the system (internal and external organizational factors) and includes legislation, policies, culture, people, processes and resources. According to Jensen (2000) systemic view is looking at whole organism of an operation, entity or business in relationship to its environment. That survival of organization depends on the surrounding environment as well as its own parts. Systemic thinking, or a systemic perspective, is reviewing not just a problem or challenge in isolation, but in the context of its surroundings.

In the literature, researcher identified many systemic factors that can affect organizational performance and corporate governance. These moderating factors include social, economic, political and legal factors (Shaukat \& Zafar, 2010). Moreover (Demil \& Lecocq, 2010) suggests that a systemic perspective provide decision makers and managers with a lean strategy design tool, to be used on a regular basis (i.e., social, environmental, and economic value forms). Similarly according to Cosenz, Rodrigues \& Rosati (2019) the system design incorporates the environmental, social and economic factors that generate value into the dynamic business model. So in line with the above discussion brief description of social, economic, political and legal factors are provided that can affect the effective implementation of corporate governance and their viable impact on organizational performance.

\section{Social Factor}

According to Ahmad (2018) social factors of Pakistan are measured in terms of estimated population $(212.2 \mathrm{M})$ and age $(64 \%$ of total population is below age 30$)$. While Ilyas et al., (2019) estimated social factors on population growth $(2.1 \%)$, population geographical factor (37\% lives in urban area), unemployment rate $(5.6 \%)$ and language (English is official and Punjabi is spoken language (48\%)). These social systemic factors may affect the induction of board of directors and executive compensation. 


\section{Economic Factor}

Pakistan is a developing country but decade of war and unstable social structure has severely affect the country's economic position (Walsh, 2013). As per PFER (2020) data, Economic factors of Pakistan are purchasing power parity $\left(27^{\text {th }}\right.$ largest in the world), gross domestic product $\left(47^{\text {th }}\right.$ largest), GDP per capita $(\$ 3149)$ and foreign currency reserves $(\$ 13.6 \mathrm{~B})$. Most of Pakistan's population pay by means of hard cash while debit card holders are $2.9 \%$ and $8.7 \%$ have bank accounts. In spite of all these debt defaults and economic crisis, Pakistan stock market is unceasingly booming, it showed exceptional performance and make new historic heights. Pakistan's stock market i.e. Karachi Stock Exchange has become the second-best performing stock market (Zafar, 2013), and ranked fourth in the world's top ten best-performing markets (CNN, 2014). In the past two years, the e-commerce sector has shown an ascending trend. According to statement of Ehsan Malik, CEO of Unilever Pakistan, quoted in the Pakistan Entrepreneurship Report "Pakistan with its nearly 200 million populations is simply too large and too attractive market to ignore" (Dawood \& Gai, 2014).

\section{Political \& Legal Factor}

Since inception Pakistan has always faced unstable political environment in the form of three military dictator eras (Cheema 2014) followed by democratic leadership of Nawaz Sharif, the head of PMLN (Pakistan Muslim League). Meanwhile corruption, bribing government officials and representatives (Qaiser et al., 2017) and lowest tax returns (Hourled, 2013) even worsen the political culture of Pakistan. Similarly lack of cyber-crime law and no practical steps in formulation of cybercrime law enforcement contaminate the legal structure of country (Ataa, 2013). Currently government is planning to establish special courts to deal with cyber disputes (Dad, 2015). Pakistan has also blur and very lenient investment policies to attract foreigners as they are allowed to have $100 \%$ equity with no local partner involvement and they can also fully repatriate the investment (Dawood \& Gai, 2014).

\section{Organizational Performance}

As per Wheelen and Hunger (2000) performance is an accomplishment of an activity and an organizational performance is sum of end results of all the organization's work process and activities. In the current study organizational financial performance is taken as dependent variable. Financial performance is the firm's ability to make profits and it is divided into three general categories: investor, accounting and perceptual returns (Orlitzky, Schmidt, \& Rynes, 2003).

Financial performance is calculated with the help of accounting returns i.e. earnings per share (EPS), price to earnings ratio, return on investment (ROI), return on asset (ROA (Orlitzky et al., 2003). Accounting-based company performance measurement standards are based on the evaluation of the company's past performance (Wang \& Clift 2009).

\section{Relationship between Executive Compensation, CEO Compensation and Organizational Performance}

The increasing number of bank failures makes it very vital to discover ways to increase their worth so as to draw investors and potential investor's attention. In order to achieve this goal, scholars have proposed from various aspects that if the desired value needs to be achieved, the person who manages the bank must be adequately compensated. Therefore, this study examines the moderating effect of equity on the relationship between executive compensation and the value of the Nigerian Listed Deposit Bank (DMB). The results showed that CEO compensation and chairman compensation have a positive impact on the value of listed banks, while the highest paid directors have a negative impact on bank value. However, when the variables are moderated along with the equity of executives, CEO compensation has a positive impact on the value of the bank, while the compensation of the chairman and the highest paid director reduce the value of the company after the moderation (Kantudu \& Zik-Rullahi, 2020). 
Another study examined executive compensation and firm performance (accounting \& marketbased measures) relationship among Indian firms by using system generalized methods of moments (GMM) estimator. Results show a significant tenacity in executive compensation among the sample firms. Further, there is absence of pay-performance relationship among the smaller sample firms and business group affiliated firms (Raithatha \& Komera, 2016). Similar results reported by Barde \& Zik-Rullahi (2020) that CEO Pay creates a positive effect on financial performance of banks, while chairman compensation and highest paid director have negative influence on banks financial performance.

In plethora of the above researches Sheikh et al., (2018) also inspects the relationship by using a more robust generalized moment method (GMM) estimation method, the impact of Pakistan's corporate performance and corporate governance on CEO compensation was studied, and it was found that the current and previous year's accounting performance had a positive impact on CEO compensation. However, the performance of the stock market does not seem to have a positive impact on executive compensation. So keeping in view of the literature, our hypothesis are as follows:

H1a: Executive Compensation has significant influence on EPS

$H 1 b$ : Executive Compensation has significant influence on ROE

H2a: CEO compensation has significant impact on EPS

$H 2 b$ : CEO compensation has significant impact on ROE

\section{Relationship between Diversity and Organizational Performance}

Schwartz (2013) documented that companies with gender-balanced boards have better corporate performance. Similarly, Herdhayinta (2014) used ordinary least squares (OLS) and two-stage least squares (2SLS) regression analysis to study 50 Asia-Pacific companies, and the results showed that the gender diversity of board members has a positive impact on financial performance (Tarus and Aime, 2014).

Pletzer et al. (2015) conducted a meta-analysis of the relationship between female representatives on the company's board of directors and the company's financial performance. The study included 20 research data from 3,097 companies published in peer-reviewed academic journals. The results showed that if other factors were not taken into account, female representatives on the company's board of directors had nothing to do with the company's financial performance. A study by Alm \& Winberg (2016) based on six-year panel data from 255 companies and found that there is no statistically significant relationship between ROA and Tobin's Q and the female gender variable; this shows that the relationship between gender diversity and performance has no clear link.

Another study used the role of corporate social responsibility (CSR) in companies listed on the Palestine Stock Exchange from 2010 to 2017 to examine how significant impact board gender diversity has on the company performance directly and indirectly. The results show that the gender diversity of the board of directors has a positive and insignificant impact on company performance. However, under the moderating effect of corporate social responsibility, it was found that the change from positive insignificant to positive and significant (Saleh et al., 2021). At the same time, Oware, \& Mallikarjunappa (2021) used the Indian stock market as a testing ground to study the family management, financial performance and gender diversification of listed companies. The results showed that the increase in stock price returns led to corresponding growth in female employment. Consistent with this study by Gong and Gilma (2021), the focus on the impact of gender diversity on business performance has been prominent in the agendas of many politicians and business leaders in recent years. The empirical results of the impact of 
gender diversity on company performance are not clear. Sensitivity analysis shows that when the proportion of female directors is about $30 \%$, gender diversity seems to have the greatest impact. One more study revealed that the board diversity has a significant influence on the performance, indicating that knowledge, skills, and abilities acquired by directors are critical for board effectiveness (Onuorah et al., 2019).

H3a: Board gender based diversity has a significant impact on EPS

$H 3 b$ : Board gender based diversity has a significant impact on ROE

\section{Systemic Factors Moderate the Relationship between Corporate Governance Issues and Organizational Performance}

Systemic factors for instance political, legal, economic, social and cultural enhance the business model worth (Cosenz, Rodrigues \& Rosati, 2019). These factors interacts with the environment by taking inputs and transforming then into outputs (Robbins, 2007). A study (Liedong \& Rajwani, 2018) conducted to study the impact of political element of systemic factors on the cost of debt with the mediating role of corporate governance and results revealed that that there is direct relationship between political ties and interest rates but corporate governance doesn't mediates the relationship. Sari \& Lubis (2018) studied the impact of culture on corporate governance and corporate performance relationship and the results shows that there is significant influence of culture on corporate governance and corporate performance relationship. Another research was conducted by Aboud and Diab (2018) in which social, environmental and corporate disclosure were taken as independent variable and firm value as dependent variable. Finding suggests that social, environmental and corporate disclosure is positively associated with the firm performance. Systemic factors is a novel variable and very few studies are available to test its moderating role in Executive compensation, CEO compensation, diversity and organizational performance relationship. So the hypothesis are as follows.

H4a: Systemic factors moderates the relationship of executive compensation and EPS

$H 4 b$ : Systemic factors moderates the relationship of executive compensation and ROE

H5a: Systemic factors moderates the relationship of CEO compensation and EPS

$H 5 b$ : Systemic factors moderates the relationship of CEO compensation and ROE

H6a: Systemic factors moderates the relationship of board gender diversity and EPS

H6b: Systemic factors moderates the relationship of board gender diversity and ROE

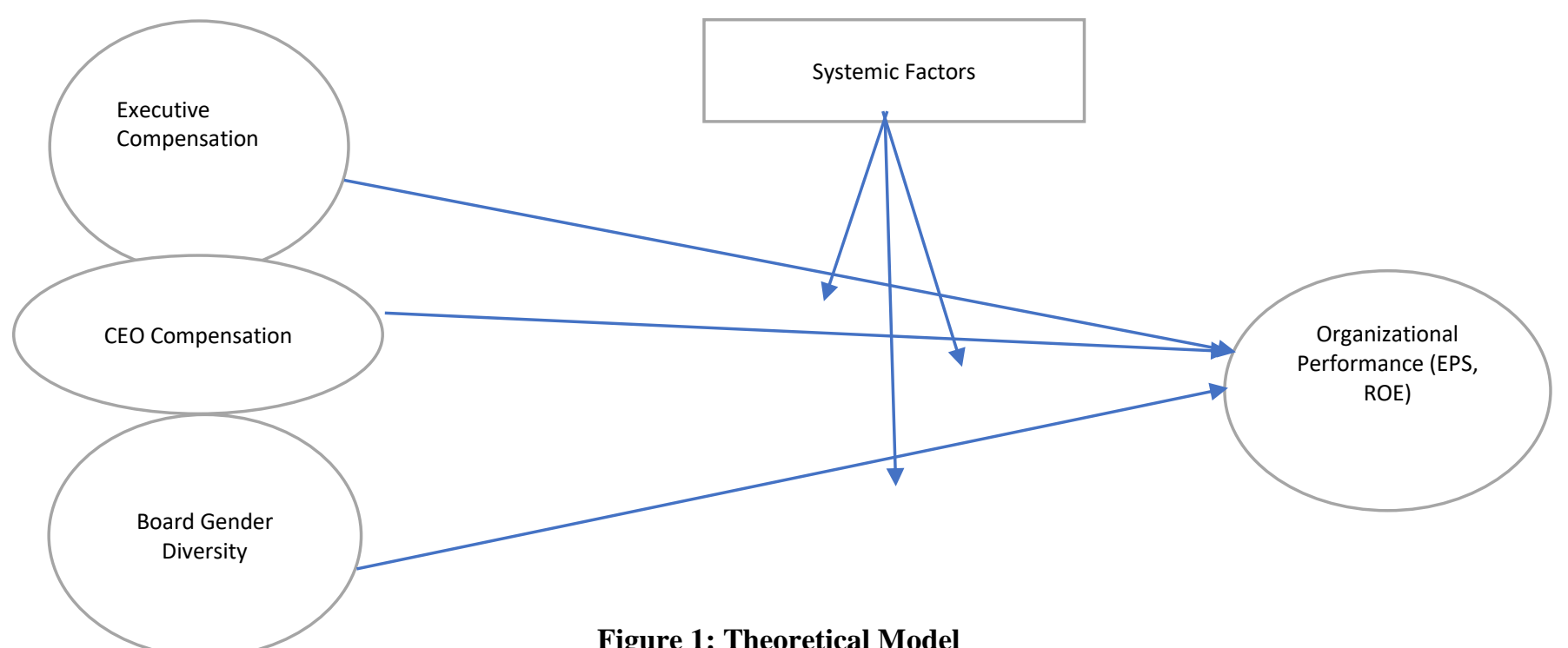

Figure 1: Theoretical Model 


\section{Research Framework}

\section{Population and Sampling}

Current study examined the moderation effect of systemic factors on executive compensation, CEO compensation, diversity and organizational performance on time series panel data of 14 public sector scheduled banks from 2015 to 2020 time span. Banking sector was chosen for the data collection and all the public sector scheduled banks were included in the study except First Women Bank Ltd.as from 2017 annual report of the said bank are not available due to audit issues. Moreover data of international banks was also given in dollars so they are also not included in current study. So out of 24 public sector scheduled banks, 14 domestic public sector banks are selected as sample.

\section{Measures \\ Executive compensation}

Data of executive total compensation is extracted from annual reports during the time period of 2015 to 2020. Moreover data of CEO compensation is also used in the study. Natural Logarithm of Executive and CEO Compensation is calculated for harmonizing the data with the rest of variables.

\section{Diversity}

Board gender diversity is being used in the current study. Data of this dimension was collected from annual reports. Board gender diversity is assessed by analyzing the board members profile data. Value 1 assigned when BOD has female member and 0 value is assigned what BOD has no female member.

\section{Organizational Performance}

Organizational performance is the dependent variable of the research. Several previous studies (Vafaei et al., 2015) have used accounting based (ROE, ROA \& EPS), others (Siddiqui, 2015) have used market-based measures (Tobin's Q, market to book ratio and Return on Stocks) to measure financial performance. In the current study accounting based measures i.e. ROE \& EPS are being used to measure the organizational performance. ROE and EPS is calculated by formula given below:

$$
\begin{aligned}
\text { ROE } & =\frac{\text { Net income after interest and tax }}{\text { Total equity }} \\
\mathrm{EPS} & =\frac{\text { Company's profit }}{\text { Outstanding shares of its common stock }}
\end{aligned}
$$

\section{Systemic Factors}

Systemic factor is the moderating variable of the research model. Data for country based systemic factors (Economic, political, social \& Legal) are extracted from the World Bank database for years 2015 to 2020 . Economic factor is measured with the help of inflation CPI, social factor assessed with the help of unemployment rate of the population, political factor measured by means of political stability and absence of violence index while legal systemic factor is calculated with the help of Rule of Law data of country. All the four dimensions are transformed into single computed variable.

\section{Data Analysis Results and Discussion}

STATA 17 was used for data analysis as researcher is using panel data in current research. Firstly, summary statistics was calculated and after that regression was used to check the direct effect of independent variable on dependent variable. In the last step, researcher used moderation analysis with the help of interaction effect.

\begin{tabular}{|c|c|c|c|c|c|}
\hline Variables & Observations & $\operatorname{Mean}(X)$ & S.D. & Min. & Max. \\
\hline
\end{tabular}

Table 1: Summary Statistics 


\begin{tabular}{llllll}
\hline & (n) & & & \\
\hline EPS* & 84 & 7.29 & 6.74 & -6.98 & 29.04 \\
ROE* & 84 & 14.79 & 15.34 & -97.2 & 43.12 \\
Exe-comp** & 84 & 20.09 & 2.08 & 18.26 & 23.24 \\
CEO-Comp** & 84 & 18.13 & 0.72 & 16.23 & 20.94 \\
BGD** & 84 & 0.404 & 0.49 & 0 & 1 \\
Ln sales*** & 84 & 24.58 & 0.86 & 22.90 & 26.32 \\
Systemic & 84 & 6.92 & 2.52 & 2.84 & 11.80 \\
Factors & & & & \\
\hline
\end{tabular}

*Dependent variable, EPS (Earnings per share), ROE (Return on Equity)

**Independent variable, Exe-comp (Executive compensation), CEO-comp (CEO compensation), BGD (Board gender diversity)

***Control Variable: Firm size (lnsales)

Table 1 summarizes the statistics of all research variables. Total observations used in the study are 84 as the researcher has used data of 14 domestic public sector banks of Pakistan covering time span of 6 years. Organizational performance is determined with the help of EPS \& ROE. Earnings per share (EPS) is the dependent variable and the finding shows that its mean score is 7.29, while minimum value is -6.98 (Sindh Bank) and maximum value is 29.04 which is depicted by MCB. ROE is also dependent variable and its mean score is 14.79 while minimum score is 97.2 depicted by Sindh bank while maximum score is 43.12 (BOP) which reveals that MCB and BOP financial position is good as they have highest EPS \& ROE respectively while Sindh bank is facing loses as both ROE \& EPS of Sindh bank is negative.

Table 2: Regression Analysis of Executive Compensation, CEO Compensation, Board Gender Diversity and EPS

\begin{tabular}{lllllll}
\hline Hypothesis & & $\begin{array}{l}\text { Standard } \\
\text { Error }\end{array}$ & $\begin{array}{l}\text { t- } \\
\text { value }\end{array}$ & p-value & Decision & $\mathbf{R}^{\mathbf{2}}$ \\
\hline H1a & $\begin{array}{l}(\mathrm{Exe} \\
\text { comp } \rightarrow \text { EPS })\end{array}$ & 0.31 & 1.83 & $0.007^{*}$ & Accepted & 0.30 \\
H2a & $\begin{array}{l}\text { (CEO } \\
\text { comp } \rightarrow \text { ESP })\end{array}$ & 0.91 & 4.57 & $0.000^{*}$ & Accepted & \\
H3a & $(\mathrm{BGD} \rightarrow$ EPS $)$ & 1.41 & 2.10 & $0.03^{*}$ & Accepted &
\end{tabular}

*Note: $\mathrm{p}<0.05$

Table 2 shows direct relationship of Executive compensation and EPS and the results of p-value shows that .007 is less than 0.05 which means that results are significant. It supports our hypothesis H1a i.e. Executive compensation has a significant impact on EPS. Literature also proves the same significant relationship as Elsayed \& Elbardan (2018) analyzed 5 year data during (2010-2014) of 350 companies and rigorous analysis found out strong evidence for the greater influence of executive compensation on firm performance. Hypothesis $\mathrm{H} 2 \mathrm{a}$ is also accepted as p-value 0000 is less than 0.05 and it shows that CEO compensation has positive significant impact on EPS. These results are also supported by Barde \& Zik-Rullahi (2020) that CEO Pay has significant positive effect on financial performance of banks. Third hypothesis H3a is also accepted as 0.03 is less than 0.05 which proves that board gender diversity has a significant positive impact on earnings per share. This relationship was also proved from the study conducted by Saleh et al. (2021) using Palestine Stock Exchange listed firms over the period 2010-2017 and results showed that BGD has a positive and significant influence on firm performance with the moderating effect of CSR. Value of $\mathrm{R}^{2}$ is 0.30 which means that model is fit and cumulative effect of executive compensation, CEO compensation and board gender on EPS is $30 \%$. 
Table 3: Regression Analysis of Executive Compensation, CEO Compensation, Board Gender Diversity and

\begin{tabular}{llccccc}
\hline \multicolumn{2}{l}{ Hypothesis } & $\begin{array}{l}\text { Standard } \\
\text { Error }\end{array}$ & $\begin{array}{c}\text { t- } \\
\text { value }\end{array}$ & p-value & Decision & $\mathbf{R}^{\mathbf{2}}$ \\
\hline H1b & Exe-comp $\rightarrow$ ROE & .800 & 1.94 & $0.05^{*}$ & Accepted & 0.15 \\
H2b & CEO comp $\rightarrow$ ROE & 2.29 & 2.66 & $0.01^{*}$ & Accepted \\
H3b & BGD $\rightarrow$ ROE & 3.53 & -1.77 & $0.08^{*}$ & Rejected
\end{tabular}

*Note: $\mathrm{p}<0.05$

Table 3 reveals direct relationship of Executive compensation and ROE and the results of p-score show that 0.05 value is significant. It supports our fourth hypothesis H1b i.e. Executive compensation has a significant impact on ROE. Above mentioned results are confirmed by study conducted by Raithatha \& Komera (2016) who explored executive compensation and firm performance relationship (accounting \& market-based measures) among Indian firms by employing the system generalized methods of moments (GMM) estimator and results depicted that there is significant impact of executive compensation on firm performance. Fifth hypothesis $\mathrm{H} 2 \mathrm{~b}$ is accepted as p-value 0.01 is less than 0.05 and it shows that CEO compensation has positive significant impact on ROE. Sixth hypothesis $\mathrm{H} 3 \mathrm{~b}$ is rejected as 0.08 is greater than 0.05 which shows that board gender diversity has no significant impact on return on equity (ROE). Alm \& Winberg (2016) confirmed current findings as results of their research found no significant link between gender diversity and organizational performance relationship. $\mathrm{R}^{2}$ value of current study is 0.15 which reveals that model fit is good and cumulative effect size of Executive compensation, CEO compensation and BGD on ROE is $15 \%$.

Table 4: Moderated Hierarchical Regression Analysis when Systemic Factors Moderates the Relationship of Executive Compensation, CEO Compensation, Board Gender Diversity and EPS

\begin{tabular}{lllllll}
\hline Hypothesis & & $\begin{array}{l}\text { Standard } \\
\text { Error }\end{array}$ & $\begin{array}{l}\text { t- } \\
\text { value }\end{array}$ & $\begin{array}{l}\text { p- } \\
\text { value }\end{array}$ & Decision & $\mathbf{R}^{\mathbf{2}}$ \\
\hline H4a & Exe-comp $\rightarrow$ EPS & 0.249 & 1.96 & $0.05^{*}$ & Accepted & 0.58 \\
H5a & CEO- & 0.89 & 0.27 & $0.78^{*}$ & Rejected \\
& comp $\rightarrow$ EPS & & & & \\
H6a & BGD $\rightarrow$ EPS & 1.10 & 1.96 & $0.05^{*}$ & Accepted \\
& Lnsales & 0.73 & 7.27 & 0.000 & & \\
\hline
\end{tabular}

*Note: $\mathrm{p}<0.05$

In table 4 results of moderated hierarchical regression analysis is presented where systemic factors (economic, social, political and legal) are used as moderating variable. Very few studies have used systemic factors as a moderating variable. H4a i.e. systemic factors moderates the relationship of Executive compensation and EPS relationship is accepted as pvalue is 0.05 . Hypothesis H5a which is systemic factors moderates the CEO compensation and EPS relationship is rejected as 0.78 is greater than 0.05 . CEO-comp $\rightarrow$ EPS direct relationship was significant but with moderating variable, relationship turns into insignificant which predict that when political, economic, social and legal factors intervene than higher CEO compensation no longer creates any impact on earnings per share. H6a i.e. board gender diversity and EPS relationship is moderated by systemic factors is accepted as p-value is 0.05 while overall model fit is $58 \%$ 
of Executive Compensation, CEO Compensation, Board Gender Diversity and ROE

\begin{tabular}{llccccc}
\hline Hypothesis & & $\begin{array}{l}\text { Standard } \\
\text { Error }\end{array}$ & $\begin{array}{l}\text { t- } \\
\text { value }\end{array}$ & $\begin{array}{l}\text { p- } \\
\text { value }\end{array}$ & Decision & $\mathbf{R}^{2}$ \\
\hline H4b & $\begin{array}{l}\text { Exe- } \\
\text { comp } \rightarrow \text { ROE }\end{array}$ & 1.07 & 1.89 & $0.06^{*}$ & Rejected & 0.68 \\
H5b & $\begin{array}{l}\text { CEO- } \\
\text { comp } \rightarrow \text { ROE }\end{array}$ & 2.26 & -2.77 & $0.007^{*}$ & Accepted & \\
H6b & BGD $\rightarrow$ ROE & 2.43 & 1.61 & $0.04 *$ & Accepted & \\
& Lnsales** & 0.80 & 6.83 & 0.000 & & \\
\hline
\end{tabular}

*Note: $\mathrm{p}<0.05$

In table 5 systemic factors are used as a moderating variable in predictor-outcome relationship. $\mathrm{H} 4 \mathrm{~b}$ i.e. systemic factors moderates the relationship of Executive compensation and ROE relationship is rejected as p-value is 0.06 which is greater than 0.05 which shows that when systemic factors moderates the relationship than Executive compensation doesn't create any significant impact on return on assets while in case of Table 4 Executive compensation creates significant impact on EPS in the presence of moderator. Hypothesis H5b which is systemic factors moderates the CEO compensation and ROE relationship is accepted as 0.007 is less than 0.05 . H6b i.e. board gender diversity and ROE relationship is moderated by systemic factors is accepted as p-value is 0.04 while overall model fit is $68 \%$.

Table 6: Summary of Moderated Hierarchical Regression Analysis

\begin{tabular}{lllll}
\hline & \multicolumn{2}{c}{ EPS Model 1 } & \multicolumn{2}{c}{ ROE Model 2 } \\
\hline & Without & With & Without & With \\
& Moderation & Moderation & Moderation & Moderation \\
$\mathbf{R}^{2}$ & .30 & .58 & .15 & .68 \\
Adjusted & .27 & .56 & .12 & .65 \\
$\mathbf{R}^{2}$ & & & & \\
\hline
\end{tabular}

Table 6 compares results of $\mathrm{R}^{2}$ with and without moderation effect. In EPS model 1, value of $\mathrm{R}^{2}$ is $30 \%$ while after systemic factors moderation value of $\mathrm{R}^{2}$ increased up to $58 \%$ which shows that model fit is improved by $28 \%$. While in ROE model 2 value of $\mathrm{R}^{2}$ is $15 \%$ without moderation while value is enhanced by $68 \%$ with moderation effect, so it reveals that model 2 fit is improved by $53 \%$.

\section{Conclusion}

Based on current analysis it's revealed that Executive compensation, CEO compensation and board gender diversity has significant impact on organizational financial performance in terms of EPS. While social, economic, political and legal factors moderates the Exe-comp $\rightarrow$ EPS \& $\mathrm{BGD} \rightarrow$ EPS relationship but systemic factor does not moderates CEO-comp $\rightarrow$ EPS relationship. Similarly when organizational performance is measured by means of ROE, then it shows that executive compensation \& CEO compensation has significant impact on ROE when BGD has no impact on ROE and systemic factor moderates the CEO-comp $\rightarrow$ ROE \& BGD $\rightarrow$ ROE relationship while it does not have any moderating impact on Exe-comp $\rightarrow$ ROE relationship. So overall results depicts that CEO\& Executive compensation and diversity can enhance organizational financial performance and systemic factor contribute in model fit that's why organizations cannot ignore the importance of systemic factors as organizations can't work in isolation and economic, social, political \& legal factors moderates the predictor outcome relationship.

\section{Limitation of the Study}

Recent study has used CPI index for analysis of economic systemic factor analysis while other 
factors can also be included in future research such as GDP growth of Pakistan. Moreover for social, political and legal data other indexes can be used apart from unemployment index (social), political stability \& absence of violence (political) and rule of law index (legal).

\section{References}

Aboud, A., \& Diab, A. (2018). The impact of social, environmental and corporate governance disclosures on firm value. Journal of Accounting in Emerging Economies.

Adams, R. B., \& Ferreira, D. (2009). Women in the boardroom and their impact on governance and performance. Journal of Financial Economics, 94(2), 291-309.

Ahern, K. R., \& Dittmar, A. K. (2012). The changing of the boards: The impact on firm valuation of mandated female board representation. The Quarterly Journal of Economics, 127(1), 137-197.

Ahmad, S. Z., Ahmad, N., \& Bakar, A. R. A. (2019). Reflections of entrepreneurs of small and medium-sized enterprises concerning the adoption of social media and its impact on performance outcomes: Evidence from the UAE. Telematics and Informatics, 35(1), 6-17.

Alm, M., \& Winberg, J. (2016). How Does Gender Diversity on Corporate Boards Affect the Firm Financial Performance?

Attaa, Amir. (Nov 27, 2013). Pakistan is Finally Preparing to Formulate Cyber Laws in the Country

Barde, I. M., \& Zik-Rullahi, A. A. (2020). Effect of executive compensation and share ownership on financial performance of listed deposit money banks in Nigeria. Journal of Accounting and Taxation, 12(1), 1-11.

Cheema, M. U. Sophia, R.M. (2014),"Political connections and organizational performance: evidence from Pakistan", International Journal of Accounting \& Information Management, Vol. 24 Iss 4 pp.1-29

CNN MONEY. (Dec 23, 2014). Best performing global markets. Retrieved from http//money.cnn.com/interactive/investing/best-performing-global-markets/

Coles, J. L., Daniel, N. D., \& Naveen, L. (2014). Co-opted boards. Review of Financial Studies, 27(6), 1751-1796.

Connelly, B.L., Tihanyi, L., Ketchen, D.J., Carnes, C.M. \& Ferrier, W.J. (2017), "Competitive repertoire complexity: Governance antecedents and performance outcomes", Strategic Management Journal, Vol. 38 No. 5, pp. 1151-1173.

Cosenz, F., Rodrigues, V.P., \& Rosati, F., (2019). Dynamic business modeling for sustainability: Exploring a system dynamics perspective to develop sustainable business models. Wiley Business Strategy and the Environment. 1-14

Dad, N. (Feb 2, 2015). A new cybercrimes law. Retrieved from http//tribune.com.pk/story/666643/a-new-cybercrimes-law/

Darmadi, S. (2011hayat). "Board diversity and firm performance: the Indonesian evidence", journal Corporate Ownership and Control, Vol 8, pp. 1-38

Dawood, A. \& Gai, (2014). Pakistan, A Frontier Market Experiencing a Startup Revolution http//dyl-ventures.com/pakistan-frontier-market-experiencing-startup-revolution/

Demil, B., \& Lecocq, X. (2010). Business model evolution: in search of dynamic consistency. Long range planning, 43(2-3), 227-246.

Elsayed, N., \& Elbardan, H. (2018). Investigating the associations between executive compensation and firm performance. Journal of Applied Accounting Research.

Gong, Y., \& Girma, S. (2021). Top management gender diversity and performance: in search of threshold effects. Cambridge Journal of Economics, 45(1), 109-127.

Haslam, S.A., Ryan, M.K., Kulich, C., Trojanowski, G. and Atkins, C. 2010, 'Investing with Prejudice: The Relationship between Women's Presence on Company Boards and objective and Subjective Measures of Company Performance', British Journal of Management, 21 (2): 484-97.

Hayat, U. (2017). "Woman Directors in Pakistan to more than double in three years", (2017, July 
3). Dawn.

Haynes, Murray, A., \& Skene, K. (2017). The circular economy: an interdisciplinary exploration of the concept and application in a global context. Journal of business ethics, 140(3), 369380.

Herdhayinta, H. (2014). The influence of board diversity on financial performance: An empirical study of Asia-Pacific companies (Master's thesis University of Agder).

Hourled, K. (Dec 23, 2013). Half Pakistani lawmakers say they do not pay tax report. Retrieved fromhttp//www.reuters.com/article/2013/12/23/us-pakistantaxidUSBRE9BM0HF20131223

Humphries, S. A., \& Whelan, C. (2017). National culture and corporate governance codes. Corporate Governance: The International Journal of Business in Society.

Jensen, K., (2000). Systemic Perspectives in Business Organization. Retrieved Sep, 23, 2020 from https://smallbusiness.chron.com/systemic-perspectives-business-organization38644.html

Kantudu, A. S., \& Zik-Rullahi, A. A. (2020). Value of Listed DMBs In Nigeria: Does Share Ownership Moderates Executive Compensation And Financial Performance Relationship? Journal of International Business Research, 19(1), 1-10.

Stellner, C., zooKlein, C., \& Zwergel, B. (2015). Corporate social responsibility and Eurozone corporate bonds: The moderating role of country sustainability. Journal of Banking \& Finance, 59, 538-549.

Lenard J. M., Yu B., York A., \& Wu S. (2014). Impact of board gender diversity on firm risk. Managerial Finance, 40(8), 787-803.

Liedong, T. A., \& Rajwani, T. (2018). The impact of managerial political ties on corporate governance and debt financing: Evidence from Ghana. Long Range Planning, 51(5), 666679.

Naveed, K., Voinea, C. L., Ali, Z., Rauf, F., \& Fratostiteanu, C. (2021). Board Gender Diversity and Corporate Social Performance in Different Industry Groups: Evidence from China. Sustainability, 13(6), 3142.

Onuorah, A. C., Osuji, C. C., \& Ozurumba, B. A. (2019). Board composition, diversity index and performance: Evidence from four major Nigerian banks. Journal of Management Information and Decision Science, 22(4), 342-359

Orlitzky, M., Schmidt, F. L., \& Rynes, S. L. (2003). Corporate social and financial performance: A meta-analysis. Organization Studies, 24(3), 403.

Oware, K. M., \& Mallikarjunappa, T. (2021). Financial performance and gender diversity. The effect of family management after a decade attempt. Society and Business Review.

Pletzer, J. L., Nikolova, R., Kedzior, K. K., \& Voelpel, S. C. (2015). Does gender matter? Female representation on corporate boards and firm financial performance-a metaanalysis. 1, 10(6),

Qaisar. B., Nadeem, S. \& Siddiqui, M.S. (2017). Relationship of Social Progress Index (SPI) with Gross Domestic Product (GDP PPP per capita): The moderating role of Corruption Perception Index (CPI). Pakistan Journal of Engineering Technology and Science (PJETS). Volume 7(1), June 2017

Raithatha, M., \& Komera, S. (2016). Executive compensation and firm performance: Evidence from Indian firms. IIMB Management Review, 28(3), 160-169.

Randøy, T., Oxelheim, L., \& Thomsen, S. (2006), "A Nordic perspective on corporate board diversity", working paper, Nordic Innovation Centre, Oslo, November

Robbins, S. P., \& Coulter, M. (2007). Management 13E. Pearson India.

Saleh, M. W., Zaid, M. A., Shurafa, R., Maigoshi, Z. S., Mansour, M., \& Zaid, A. (2021). Does board gender enhance Palestinian firm performance? The moderating role of corporate social responsibility. Corporate Governance: The International Journal of Business in Society.

Sari, M., \& Lubis, A. D. (2018). The influence of organization's culture and internal control to 
corporate governance and is impact on bumn (state-owned enterprises) corporate performance in indonesia. J. Advanced Res. L. \& Econ., 9, 681.

Schwartz-Z, M. (2013). Does the gender of directors matter? (SSRN Working Paper Series No. 8). Edmond J. Safra Center for Ethics, Harvard University.

Shaukat, M., \& Zafar, J. (2010). Impact of sociological and organizational factors on information technology adoption: An analysis of selected Pakistani companies. European Journal of Social Sciences, 13(2), 305-320.

Sheikh, M. F., Shah, S. Z. A., \& Akbar, S. (2018). Firm performance, corporate governance and executive compensation in Pakistan. Applied economics, 50(18), 2012-2027.

Smith, N., Smith, V., \& Verner, M. (2006). Do women in top management affect firm performance? A panel study of 2,500 Danish firms. The international journal of productivity and performance management, 55, 569-593.

Talavera, O., Yin, S., \& Zhang, M. (2018). Age diversity, directors' personal values, and bank performance. International Review of Financial Analysis, 55, $60-79$.

Tarus, D. K., \& Aime, F. (2014). Board demographic diversity, firm performance and strategic change: A test of moderation. Management Research Review.

Walsh, D. (18 May 2013). "Pakistan, Rusting in Its Tracks". The New York Times.

Wang, Y. and Clift, B. 2009, 'Is There a "Business Case” for Board Diversity?' Pacific Accounting Review, 21 (2): 88-103.

Wheelen T.L and Hunger J.D (2000), "Strategic Management", 7th edition, Prentice Hall, U.S.A, pp231-235.

Zafar, Farukh. (Oct 6, 2013). Why and how KSE became the world's second-best performing market this year. Retrieved from http//tribune.com.pk/story/614407/record-making-whyand-how-kse-became-the-worldssecond-best-performing-market-this-year/

Zooning, F. (2017). Agency theory: A critical review. European journal of business and management, 9(2), 1-8. 